\title{
CLIMATE CHANGE AND LAKE WATER RESOURCESIN SUB-SAHARAN AFRICA: CASE STUDY OF LAKE CHAD AND LAKE VICTORIA
}

\author{
D. A. Yunana ${ }^{1,{ }^{*}, \text { A. A. Shittu2 }}{ }^{2}$, S. Ayuba ${ }^{3}$, E. J. Bassah ${ }^{4}$ and W. K. Joshua ${ }^{5}$ \\ 1,2,3,4,5 Department of Civil EngineERIng, Federal University Wukari, Taraba State, NigERIA. \\ E-mail addresses: ${ }^{1}$ agaidehdanladi4real@gmail.com, ${ }^{2}$ hakimabdul05@yahoo.co.uk, ${ }^{3}$ solos4life@yahoo.com, \\ 4 johnbassah@yahoo.com, 5 willjosh2003@yahoo.com
}

\begin{abstract}
This review assesses the impact of climate change on lake water resources in Sub-Saharan Africa(SSA). Two significant global water features with immense contribution to agriculture and socio-economic development of the region were analysed. Lake Victoria is the world second largest freshwater lake and Lake Chad the largest endoreic basin. These two great water bodies have been affected drastically by climate change and human influence. A significant shrinkage on Lake Chad was experienced with a decrease in water stored from $40-100 \times 10^{9} \mathrm{~m}^{3}$ in 1960 s to less than $72 \times 10^{9} \mathrm{~m}^{3}$ in 2005. This effect abruptly receded Lake Chad from $25,000 \mathrm{Km}^{2}$ in the 1960 s to $1350 \mathrm{Km}^{2}$ in 2005; while Lake Victoria experienced continual fluctuations from over a century; with evaporation rates varying between 1370mm to $1600 \mathrm{~mm}$, 90\% of water loss which leads to peak fluctuation occurring in 1961.
\end{abstract}

Keywords: Water Resource, Climate Change, Sub-Saharan Africa, Lake Chad, Lake Victoria

\section{INTRODUCTION}

Freshwater availability and water use have been recognized as global issues, and their consistent quantification is required to provide an integrated view of the water situation on earth. The challenge and possible threats related to global change, including climate change, also affect hydrological research which currently undergoes a change in focus, driven by increasing global and complex water problems [1]. According to Evan and Slobodan [2], the demand for fresh water is rising but a variety of factors including population growth, water pollution, economic progress, land use change and climate change render its availability into the future uncertain. The awareness of growing water shortage has led to increasing interest in global modeling of water resources, both in terms of supply and demand, with the aim of developing and implementing appropriate water resource infrastructure and management strategies [3].

According to a review carried out by Joshua and Sherry [4], the world is facing serious water issues; presently, in many developing countries, current levels in water use are unsustainable, with systems susceptible to collapse from even small changes in water availability. The need for scientifically-based assessment of the potential impact on water resource of future changes, as a basis for society to adapt to such changes, is strong for most part of the world [1]. Although the focus of such assessment has tended to be climate change, socio-economic changes can have a significant impact on water availability on the four main use sectors, i.e. domestic, agricultural, industrial (including energy) and environmental. Withdrawal and consumption of water is expected to continue to grow substantially over the next 20-50 years [5] and constant changes in availability may drastically affect society and economic growth. Most of the earth's living resources are found in specific geographical locations such as the global coastal environment and the catchment basins of large river systems ([6] cited in [7]). Furthermore, Michael [7] stated that a large portion of the world's population live in close proximity to these regions and its frequent dependent upon it for either part or much of food supply and industrial raw materials. The consequence of this situation is that much of the waste, both industrial and domestic, and various other types of habitat disturbances (e.g. aquaculture, deforestation, erosion of agricultural land, soil contamination, mangrove forest and coral reef destruction, land reclamation dredging etc) generated by the human populations occurs in those areas that are of greatest biological and economic significance. Hence, the potential for deleterious impact in both environmental and economic terms is immense, but has in the past 
generally taken a relatively low priority in the context of global socio-economic systems [7].

Sub-Saharan Africa (SSA) is blessed with abundant minerals, forests, wildlife and rich biological diversity. However, these natural resources are largely unexploited and do not reflect the welfare of the inhabitants in the region [8]. This section of the African continent can boast of some of the world's biggest tropical rain forests and highest equatorial mountains. Strategic natural resources are unevenly repartitioned. For instance, more than 20 percent of the remaining tropical forest is in the Democratic Republic of the Congo, while the river Congo, river Niger, the river Nile, river Zambezi, Lake Victoria and Lake Chad detain more than half of SSA's fresh water resources [9]. Many countries in SSA are experiencing water stress. According to EU institute for security studies, Somalia, Central Africa Republic, Sudan, Chad, Niger, Malawi, Tanzania, Ethiopia, Nigeria, Kenya and a host of other countries are suffering from serious water stress [10]. A country or a region is termed water stressed when the population is using more than 20 percent of their renewable water resources [11], whereas water withdrawals over 40 percent means such a country is experiencing severe water stress [12]. For instance, reports indicate that water withdrawal in Nigeria during the 1990s stood at 28 cubic metres per person per annum [13]. Many water supply sources (rivers, lakes, ground water basins etc.) are already over allocated, suffer degraded water quality and are often not in sufficient condition to support endangered species [14].

Climate change will exacerbate water challenges (through drought, water scarcity and reduced rainfall), leading to insufficient water for people and the environment and making it increasingly difficult to meet the needs of water demand for domestic, agricultural as well as industrial needs. This review assesses the impact of climate change on Lake Chad and Lake Victoria in SubSaharan Africa.

\section{CLIMATE CHANGE}

The presence of greenhouse gases due to anthropogenic activities has impacted on global temperature and precipitation in the last century [15][16]. The intergovernmental panel on climate change [17] predicts that surface global temperature will rise between 1.4 $5.8^{\circ} \mathrm{C}$ by 2100 as a result of increase in concentration of greenhouse gases, mainly carbon dioxide [15]. According to IPCC report presented by Boko et al. [18], Africa has observed temperature rise especially in between the late 1960 s to 80 s. Temperature across Africa are predicted to rise by $2-6^{\circ} \mathrm{C}$ over the next 100 years and rainfall variability is predicted to increase, resulting in frequent flooding and drought [19]. According to a report on regional climate projections 2007 by IPCC presented in Gemeda and Sima [15], that by 2050 the mean temperatures in Africa will rise from $1.5-3^{\circ} \mathrm{C}$ and that the warming of Africa is very likely to be larger than the globe. The impact of the rise in temperature as predicted together with rainfall variability will reduce crop productivity in low income and agriculture dependent economies.

Increase in temperature and decline in rainfall in Sahelian and Sub-Saharan countries especially Sudan, Senegal, Mali, Chad, Niger and Eritrea that are mainly subsistence and small scale farmers will experience severe risk to their livelihood [20]. The poor and marginalized usually have the least buffer to face even the modest climate hazards and suffer the most from frequent events with little time for recovery [21].Recent research by Rose [22], Signgh and Purohit [23], Nordhaus [24] shows that African countries are more affected by the impact of climate change because of their reliance on agriculture as well as their lower financial, technical and institutional capacity to adapt and mitigate climate change. The African continent is expected to be the most affected by climate change, desertification and land degradation [20]. Though Africa is the least producers of Green House Gas (GHG) emissions from inhabited continents, it is the most vulnerable to the effects of climate change and global warming $[15,25,26]$.

\subsection{Climate Variability and Change in Africa}

Lake chad location within the borders separating chad, Cameroun, Niger and Nigeria is geographically significant in West-Central Africa because of its cultural and socio economic prominence as the regions agricultural heart land [27]. According to Lake Chad basin commission report 2014, the Lake was the world's sixth largest inland water body.

\subsection{Climate Change Impact on Water Resources}

Consistently, Climate study has provided munificent evidence that water resources are prone and will greatly be impacted by variability in the climate, with resulting effect on societies' and ecosystems [28]. However, Field, et al., [29] pointed out that warmer air temperature is expected to have several impacts on water resources including snow pack and increasing evaporation, which affects the seasonal availability of water. Bates, et al.[30] is critical of the tendency of changes to occur in oceans, lakes and rivers as a result of global warming following observatory study with implications for freshwater ecosystem, such as changes in water salinity, water nutrient resulting in overall water quality impairments. Some studies investigating water resources in Africa indicates that climate change and variability are likely to impose additional pressure on water availability, water 
accessibility and water demand in Africa [31]. An argument by Ashton [32], pointed out that even without climate change, several countries in Africa, particularly in northern Africa, will extend the limits of their economically usable land- based water resources before 2025. In 2003, a study by Vorosmaty et al. [12] reveals that about $25 \%$ of Africa's population experienced high water stress. An assessment by Arnell [33] predicted an increase in population at risk to water stress in Africa to rise to $75-250$ million and a likely increase to between 350-600 million people by 2020 and 2050 respectively. SSA are most vulnerable to devastating impacts of climate change because of their geographical location, low income, low technological and institutional capacity to adapt to rapid changes in the environment, as well as their greater reliance on climate sensitive renewable resources such as water and agriculture [31, 34, 35].

\section{WATER RESOURCES IN SUB-SAHARAN AFRICA}

According to the Food and Agriculture Organisation report [36], the entirety of renewable freshwater resources occurring globally is estimated at over $43,802 \mathrm{~km}^{3}$, with $3,931 \mathrm{~km}^{3}$ of this volume occurring in Africa. This figure represents 9 percent of the total freshwater resources, lagging behind South America and Asia with $28.3 \%$ and $15.7 \%$ respectively. Furthermore, the FAO [36] puts available renewable water availability of Africa at $4,008 \mathrm{~m}^{3} /$ capita/year far below the global value of $6,498 \mathrm{~m}^{3} /$ capita/year, despite one third of the world's international river basin been found in SSA (table 1). A review by UNEP [37] shows that Africa has over 160 lakes covering $25 \mathrm{~km}^{2}$ and over 22 large river basins. These major river basins are found to contain three quarter of the total freshwater in Africa. UNECA report [38] clearly reveals this and further presented that there are thirty-five countries sharing 17 major river basins in the region.

\subsection{Distribution of Water Resources}

According to United Nations Economic Commission for Africa, UNECA [38] reported and described the water resource in Sub-Sahara Africa to occur in rivers, lakes, dams, wetlands, estuarine and groundwater aquifers, with widespread limited ground water representing 15 percent of the continent's renewable water. The limited ground water is the source of drinking water for threequarter of the continents populace. Africa boasts of a combined capacity of lakes and dams 20 times that of Latin America's in terms of volume [39]. A systematic study reveals the uniqueness of Africa's Water lakes with Lake Victoria been the world's second largest freshwater lake, covering approximately $68,600 \mathrm{~km}^{2}[40]$. Lake Chad is Africa's $4^{\text {th }}$ Largest Lake when defined in terms of surface area $\left(25,000 \mathrm{Km}^{2}\right)$, this also is Africa's shallowest lake yet the world's largest endoreic basin [41].

\section{FUTURE OF WATER RESOURCES IN SUB-SAHARA AFRICA}

The population in SSA is expected to increase from 700 million in 2007 to 1.1 billion in 2030 and 1.5 billion by 2050 and will become increasingly urban by implication. Climate change and variability have the potential to impose additional pressure on water availability, water accessibility and water demand in Africa [18]. Water resources particularly comprise one sector that is highly dependent on and influenced by climate change, this is observed in the gradual yet dramatic disappearance of glaciers on Mount Kilimanjaro as a result of global warming [17]. This view is supported by Desanker [42] who said that an estimated $82 \%$ of the ice caps that crowned the mountain when it was first surveyed in 1912 is gone. He further added that a recent projection if recession continues at the present rate, will affect the majority of the glaciers on the mountain. In the 1960s, Lake Chad was about $25,000 \mathrm{~km}^{2}$ in surface area, but it experienced a rapid shrinkage in the early 1970 s and has since been fluctuating between 2000 and $15,000 \mathrm{~km}^{2}$ depending on the season [44]. The significant shrinkage experienced since 1960s is due to combination of climate variability and human influence [4].

Table 1 Comparative tables of internal renewable freshwater resources by world region

\begin{tabular}{cccc}
\hline Continent/Region & Volume per year $\left(\mathrm{km}^{3}\right)$ & $\begin{array}{c}\text { Percentage of World Fresh } \\
\text { Water Resources }\end{array}$ & $\begin{array}{c}\text { Per Capita }\left(\mathrm{m}^{3} / \text { year }\right) \\
(2008)\end{array}$ \\
\hline World & 43802 & 100.0 & 6498 \\
Africa & 3931 & 9.0 & 4008 \\
Asia & 12393 & 28.3 & 3037 \\
South America & 12380 & 28.3 & 32165 \\
Central America \& & 781 & 1.8 & 9645 \\
Caribbean & 6877 & 15.7 & 15166 \\
North America & 892 & 2.0 & 32366 \\
Oceania & 6548 & 14.9 & 8941 \\
Europe & & & \\
\hline
\end{tabular}




\subsection{Justification of Selected Case Studies}

A longitudinal study of the historical trends of Lake Chad by the Lake Chad Basin Development Commission pointed out that the lake covered 2 million $\mathrm{km}^{2}$ in 50,000BC. However, in 1963 the lake surface area fluctuated between 22,903 to $25,000 \mathrm{~km}^{2}$; in 2008 the surface area of the lake receded to $2500 \mathrm{~km}^{2}$ [42]. This Detailed examination shows that Lake Chad covers less than $10 \%$ of the area it occupied in 1960s. According to Salkida [45], the Lake Chad basin is one of the world most important agricultural heritage sites, providing a lifeline to nearly 30 million people in four riparian countries - Cameroun, Chad, Niger and Nigeria. In retrospect, FAO has called situation of the shrinkage of the lake an "ecological catastrophe" predicting that the Lake Chad could disappear in this century. Lake Victoria on the other hand as presented by Lake Victoria Fisheries Organization has the fastest growing population in east Africa with over 30 million dwellers, a third of the combined population of the east African states. Much of this population has the lake resources as source of its livelihood. Lake Victoria is one of the great lakes in Africa attested as the world's second largest lake covering $68,800 \mathrm{~km}^{2}$ in 2012 [59]; the lake resources have great value in terms of fishery, employment, income and export earnings [46].

The relevance of these lakes is clearly supported by the findings on the evolutionary significance in fishery, source of livelihood, great economic value, significant surface and catchment area and evidence of been greatly impacted by climate change. Taken together, these findings suggest the role the Lakes play in enhancing survival and sustainable development in the SSA.

\subsubsection{Lake Victoria}

Several Studies has highlighted the features of Lake Victoria. According to URT [46] as cited by [47], Lake Victoria is the second largest freshwater lake in the world with three riparian countries namely: Tanzania occupying $49 \%\left(33700 \mathrm{~km}^{2}\right)$ of the lake, Kenya occupying $6 \%\left(4100 \mathrm{~km}^{2}\right)$ and Uganda occupying $45 \%$ $\left(31000 \mathrm{~km}^{2}\right)$. The study further hinted it as the largest Lake in Africa with a surface area of $68,800 \mathrm{~km}^{2}$ and a catchment area of $193000 \mathrm{~km}^{2}$. The main rivers flowing into the lake from the Tanzanian catchment are Mara, Kagera, Mirongo, Grumeti, Mbalageti, Simiyu and Mori. Lake Victoria stretches $412 \mathrm{~km}$ from north to south, between latitudes $13^{\circ} 0^{\prime} \mathrm{N} 14^{\circ} 0 \mathrm{E}$ and $355 \mathrm{~km}$ from west to east between longitudes 31037' and 34053' E [46]. A hydro-climatic study by Swensen and Wahr [40], showed that Lake Victoria had a mean water depth of about $40 \mathrm{~m}$ and maximum depth of $92 \mathrm{~m}$ with a total length of $344 \mathrm{~km}$ and $240 \mathrm{~km}$ in width and occupying a catchment area of
$180,950 \mathrm{~km}^{2}$. According to Nicholson [48], most of the region around the lake can be classified as arid or semiarid with a relatively high mean annual rainfall of $1200 \mathrm{~mm}-1600 \mathrm{~mm}$. He also found that the mean estimated evaporation from the lake varies between $1370 \mathrm{~mm}$ to $1600 \mathrm{~mm}$. This evidence indicates that the mean annual evaporation is more or less equal to annual rainfall in the lake. Majority of the people are subsistence farmers, fishermen and businessmen and few are employees [47].

\section{Fluctuation of Lake Victoria Levels}

The evaporation of Lake Victoria would make a particular sensitive indicator for climate change as 90 percent of its water is lost by evaporation [48]. Lake Victoria is faced by abrupt level fluctuations and a significant aberration in hydrological patterns [49]. Furthermore a great deal of fluctuation was observed in the Lake Victoria Between 1900 and 2010, with peak level occurring in 1961. Nicholson [48] reveals in his studies that the low lake level makes the immediate environs and the stretch of river Nile vulnerable to drought resulting in the displacement of people in the region. Lake Victoria has a maximum length of $337 \mathrm{~km}$, maximum width $250 \mathrm{~km}$ with a surface area of 68,800 $\mathrm{km}^{2}$ and an average depth of $40 \mathrm{~m}$ and Maximum depth of $83 \mathrm{~m}$. It has a stored water volume of $2750 \mathrm{~km}^{2}$ as at 2008 [58].

\subsubsection{Lake Chad}

The Lake Chad basin with a surface area of $25,000 \mathrm{~km}^{2}$ in the $1960 \mathrm{~s}$ is the largest endoreic basin in the world and estimated $8 \%$ of total African land surface area [41]. According to Olivry et al., [50], the Lake Chad basin encompasses three climatic zones (Sudan Zone, Sahara Zone and Sahel Zone) with an average annual rainfall generally decreasing from the south of the lake to northwards of the Lake. The three precipitation regimes present in the basin are between $500-1000 \mathrm{~mm}$ in Sudan zone, $100-150 \mathrm{~mm}$ in the Sahel zone and less than $100 \mathrm{~mm}$ in the Sahara zone. The major cities in the drainage region include N'Djamena, Icawo, Maiduguri and Maroua. Recent research suggested that annual rainfall in the region ranges between $1500 \mathrm{~mm}$ $1600 \mathrm{~mm}$ from the northern to the southern part; the lake depth varying between $4-8 \mathrm{~m}$ northwards and $2-4 \mathrm{~m}$ southwards with a mean value of $1.5 \mathrm{~m}[35,51]$. Similarly, Edmun et al., [52] found that the basin is dominated by the lagone-chari-river which account for $96 \%$ of water inflow into the Lake Chad and the region been hot and dry, evaporation rate reaches a peak of $2,300 \mathrm{~mm}$ per year. The studies presented thus far provide evidence that the potential for evaporation far outweighs the rainfall in the region. FAO [53] reported a 
decrease in fish production from 220,000 tonnes of fish in the 1960 s to about 100,000 tonnes in 2000 . Recent annual yields are placed at 50,000 to 60,000 tonnes [54][55][53]. Similarly, low outputs have been reported for crops (e.g. sorghum declined from 328,000 tonnes to about 130,000 tonnes between the late 1960s and the years following 2010) [27]. Livestock declined nearly $2 \%$ per year since the 1960s [55][56]. Also, there had been recent animal yields which are placed at about 60,000 tonnes in 2007 and below 50,000 tonnes as at 2012 [54] [55][53].

\section{Shrinkage of Lake Chad Basin}

According to Eboh et al.[35]there is a synergy resulting from climate variability and unsustainable water project which had significantly deterred the inflow of rivers that drain into the Lake Chad; this however, has resulted in the receding of the lake. Furthermore, Lemoalle [43] showed that in the 1960s, Lake Chad was about $25,000 \mathrm{Km}^{2}$ in surface area, but it experienced a rapid shrinkage in the early 1970 s and has since been fluctuating between 2,000 and $15,000 \mathrm{Km}^{2}$, depending on season. The significant shrinkage experienced since 1960s is due to a combination of severe drought and irrigation water abstraction [57]. Hydrological observation for over 3 decades reveals that the volume of water stored in the lake decreased from $40-100 \times 10^{9} \mathrm{~m}^{3}$ in 1962 to $7-72 \times 10^{9} \mathrm{~m}^{3}$ in 2005 . However, this resulted in about 90 percent of the originally inundated area been exposed in the 1970s [50]. Fish production which is a major source of traditional livelihood in the basin is greatly threatened, with decrease in production by a 50 percent, from 140,000 tons in 1966 to 70,000 tons in 1980s[51] and to less than 50,000 tonnes in 2012 [53][54][55].

\section{CONCLUSION}

This review set out to assess the impact of climate change on water resources in SSA. The most obvious finding that emerge from Lake Chad and Lake Victoria as Case studies is that; climate change has a significant adverse effect on water resources. The variability in climate results in enormous shrinkage and continuous seasonal fluctuations in the Lakes respectively. It is obvious that low adaptive measures as a result of technological deficit and visible dearth in the science of climate have made millions vulnerable. These findings emphasize the need for an effective water management adaptive strategy that will help dwellers adapt to the negative impact of climate change especially on water resources.

\section{RECOMMENDATION}

Climate change and variability combined with population growth will continue to impact on the environment.
Water resources will be best protected from climate change in sub-Saharan Africa by a deliberate and consistent strong synergy of all national governments of the regions, all international and local agencies and inhabitants of the region to develop a practical, workable and sustainable frame work. Finally, a sustainable water project should be firmly and consistently adhered to and implemented.

\section{REFERENCES}

[1] Lucas. M, Alejandra. M. Current state and future development of blue water availability and blue water demand: A view at seven case studies. Journal of Hydrology 384 245-263. 2010.

[2] Evan GRD and Slobodan PS Global water resources modelling with an integrated model of the socioeconomic-environmental system. Advances in water resources 34 684-700, 2011.

[3] Alcamo J, Doll P, Henrichs T, Kaspar F, Lehner B, Rösch T, Development and testing of the Water GAP 2 global model of water use and availability. Hydrological Science 48 317-338, 2003.

[4] Joshua W.K and Sherry W.A-P : The Combined Effect of Human Influence and Climate Variability on Water Bodies. A case study of receding Lake Chad in Sub-Saharan Africa. International Journal of Advanced Research Volume 3, Issue 6, 800-808, 2015.

[5] Cosgrove W and Rijsberman F. World Water Vision Making Water Every bodies business. Earth Scans London. 2002.

[6] Costanza R. D, Arge R, De Groot R, Farber S, Grasso M, Hannon B, Limburg K, Naeem S, O'Neill R.V, Paruelo J, Raskin R.G, Sutton P, Van Den Belt M, the value of the World's ecosystem service and natural capital. Nature 387 (1997)253-260, 1997.

[7] Michael N. Moore, Bio-complexity: the post genome challenge in ecotoxicity. Aquatic toxicology 59(2002) 1-15. 2002.

[8] Custers and Matthysen, :Africa's natural resources in a global context. International Peace information service (IPIS), 2009.

[9] Urama, K.C and Ozor, N: Impacts of climate change on water resources in Africa: the role of adaptation. African Technology Policy Network, 29, 2010.

[10] Friertas, A: Water as a stress factor in Sub-Saharan Africa. A European un ion institute for security Studies Brief; February 2013 QN-AK-13-012-2A-N ISSN 2315-1110, 2013

[11] Vorster, M. Climate change related human security threats to border integrity and safeguarding for south Africa(Doctoral Dissertation) 2014.

[12] Vorosmarty, C.J, E.M Dougla, A.A Green and C. Ravenga: Geospatial indicators of emerging water 
stress: an application to Africa. A journal of Human Environment, AMBIO 34(3): 230-236, 2005.

[13] World Bank(2003) World Development Report Sustainable Development in a dynamic world. Transforming Institutions, Growth, and Quality of Life. World Bank Washington DC. 2003.

[14] Natural resources defence council(NRDC): Climate Change, Water, and Risk: Current Water Demands Are Not Sustainable. Assessed from https://www.nrdc.org/sites/default/files/WaterRi sk.pdf 2010.

[15] Gemeda D. O. and Sima A. D. The impacts of climate change on African continent and the way forward. Journal of Ecology and the Natural environment vol. (7) $\mathrm{pp}$ 256-262. 2015.

[16] Nicholson, S. E . Climate and environmental change in Africa during the last two centuries, Climate research, 11(2), 123-144, 2010.

[17] Intergovernmental Panel on Climate Change, IPCC, (TAR) Third Assessment Report (TAR) of the Intergovernmental Panel on Climate Change. Parts 1, 2 and 3, Synthesis Report and Policy Makers Summaries. Cambridge University Press, Cambridge, UK. 2001.

[18] Boko, M.,I. Niang, A. Nyong, C. Vogel, A. Githeko, M. Medany, B. Osman-Elasha, R. Tabo and P.yanda Africa climate change 2007: Impacts: adaptation and vulnerability. Contribution of working group II to the fourth assessment report of the intergovernmental panel on climate change, M.L, Parry, O.F Canziani, J.P Palulikof, P.J Van der Linden and C.E Hansen, Eds., Cambridge University press, UK, 433-567, 2007.

[19] Hulme M, Doherty R, Ngara T, New M, Lister D . Africa climate change: 1900-2100. Clim. Res. 17 (2): 145-168. 2001.

[20] Hummel D. Climate change land degradation and migration in Mali and Senegal - some policy implications, migration in development. Institute of Social -ecological Research, Hamburger Allee 45, 60486 Frankfurt/ Main German. 2015.

[21] Olsson L. M., Opondo P., Tsahakert A., Agrawal S. H., Eriksen S. M., Perch L. N., Zakieldeen S. A. (2014): Livelihoods and poverty in: Climate change Impact Adaptation and Vulnerability, part A: Contribution of working Group 11 to the Forth Assessment Report of the IPCC. 2014.

[22] Rose R. M. the impact of climate change an human security in the sahel region of Africa. Danish Journal of African studies and Development 1(2): 009-014, 2015.

[23] Signgh A, Purohit B :Public Health Impact of Global warming and Climate Change. Peace Rev. J. Soc. Justice 26:1, 112-120, 2014.
[24] Nordhaus W. Geograph and Macro economics: New Data and findings Proc. National academy of Science 103: 3510-3517, 2006.

[25] Bewket W. Climate change perception and Adaptive response of smallholder famers in central Highlands of Ethopia, International Journal of environmental studies 69(3): 507-523. 2012.

[26] Beg N, Meriot J. C., Davidson O., Afrane-Okesse Y., Tyani. L, Denton F., Sokona Y, Thomas J. P., Thomas J. P., La Rovere E, Parikh J. K., Rahman A. A. Linkages between climate change and Sustainable development. Climate policy 2(2-3):129-144. 2011.

[27] Uche T. O., Lindsay C. S., Andrew J. D. Lake drying and livelihood dynamics in Lake Chad: Unravelling the Mechanism, context and responses. Ambio 2016 (45) 781-795. 2016.

[28] Ribeiro, M.M, Lesenno, C, Dworak, T, Massey, E., Swart, R, Benzie, M, and Laaser, C Design of guidelines for the elaboration of regional climate change adaptations strategies. Ecological institute, Vienna. 2009.

[29] Field et al., Climate Change , Impacts, Adaptation, and Vulnerability. Contribution of Working Group II to the fourth Assessment report of the Intergovernmental Panel on Climate Change, Cambridge: Cambridge University Press, 2007.

[30] Bates, B. C., Kundzewicz, Z. W., Wu, S. and Palutikof, J. P (eds): Climate change and water: technical paper of the intergovernmental panel on climate change. IPCC secretariat, Geneva: 210. 2008.

[31] Riebeck, H,: Lake victoria's falling waters. Earth observatory features, NASA. http://earthobservatory.nasa.gov/study/victoria/p rintall.php. 2006.

[32] Ashton, P.J, Avoiding conflicts over Africa's water resources. $A M B I O$, 31, 236 -242, 2002.

[33] Arnell, N. W., Climate change and global water resources: SRES emissions and socio-economic scenarios. Global Environ. Chang., 14, 31-52. 2004.

[34] Mendelsohn, R, A. Dinar and A. Dalfelt Climate change impacts on African agriculture. Preliminary analysis prepared for the World Bank, Washington, District of Columbia, 25pp. 2000.

[35] Eboh, E. C. Introduction: Debating policy options for natural development; Enugu forum policy paper IV. African institute of Applied Economics (AIAE), Enugu, Nigeria: $\quad 9-12$ available at http://aiaenigeria.org/publications/policypaperIV (pdf) assessed 10 $0^{\text {th }}$ September, 2016, 2009.

[36] FAO AQUASTAT database. Food and agriculture organization of the United Nations. https://www.fao.org/nr/aquastast assessed on $5^{\text {th }}$ September, 2016. 2009. 
[37] UNEP. Global environmental outlook. London: United Nations Environmental Program (UNEP), Earth scan. 2000., 1999.

[38] UNECA (United Nations Economic Commission for Africa). Transboundary River/Lake Basin Water Development in Africa: Prospects, Problems, and Achievements. Addis Ababa, Ethiopia: UNECA, 2000.

[39] Walling, D. E. Hydrology and rivers. In: Orme, A. (ed.) The Physical Geography of Africa. Oxford University Press, Oxford 1996.

[40] Swenson S and Wahr J Monitoring the water balance of Lake victoria, East Africa, from space. Journal of Hydrology 370 (4-jan), 2009.

[41] UNEP Fortnam, M. P and Oguntola J. A. (eds). Lake Chad Basin, GIWA Regional Assessment 43. University of Kalmar: Kalmar, Sweden. 2004.

[42] Desanker P. V. Impact of Climate Change on Life in Africa. c/o WWF US 1250 24th Street, NW Washington DC 20037 USA. UNT Digital Library. http://digital.library.unt.edu/ark:/67531/metadc2 26663/. Accessed September 20, 2016. 2010.

[43] Lemoalle, J., Lake Chad : a changing environment, In Dying and dead seas, J. C. J. Nihoul, P. O. Zavialov and P. P. Micklin (eds), NATO ARW/ASI Series, Kluwer Publ., Dordrecht, pp 321-340. 2004.

[44] Lake Chad Basin Commision, (LCBC) Integrated River Basin Management: Challenges of the Lake Chad Basin. Vision 2025. 2000.

[45] Salkida A. Africa's Vanishing Lake Chad, United Nations Africa Renewal, 2012.

[46] URT United Republic of Tanzania: National Water Policy: Ministry of Water and Livestock Development. Dares Salaam, Tanzania: Government Printer, 2002.

[47] Musamba Emmanuel, Impact of Socio-economic Activities around Lake Victoria: Land Use and Land Use Changes in Musoma Municipality, Tanzania, $J$ Hum Ecol, 35(3): 143-154 2011.

[48] Nicholson, S. E. Historical fluctuations of Lake Victoria and other Lakes in the Northern Rift valley of East Africa. J. T. Lehman (ed.), Environmental Change and Response in East African Lakes, Kluwer Academic Publishers: Netherlands, pp. 7-35, 1998.

[49] Phoon, S. Y, Shamseldin, A. Y and Vairavamoorthy: assessing impacts of climate change in Lake Victoria basin, Africa. Proceedings of the 30 th WEDC International conference, Vientiane, Lao, PDR. 2004.

[50] Olivry J.C. L, Chouret A, Vuillaume G, Lemoalle J, Bricquet J.P :Hydrology du lac Tchad. Editions Orstom, Paris France. 1996.

[51] Ngounou, B. N : water resources protection in the Lake Chad basin in the changing environment. European water 25/26: 3-12, 2009,

[52] Edmunds, W. M., Fellman, E. and Goni, I. B. Lakes, groundwater and paleohydrology in the Sahel of NE Nigeria: evidence from hydrogeochemistry. J. Geo. Soc. London, Vol. 156: 345 -355, 2009.

[53] Food and Agricultural Organisation (FAO): Climate change implications for fishing communities in the lake chad basin. In food and agricultural organisation fisheries and Aquaculture proceedings 25 Rome Italy. 2012.

[54] Murray S. Lake chad fisherman pack up their nets. RBC news retrieved Oct. 102015 from http://news .bbc.co.uk/1/hi/world/Africa/626-1147.stm, 2007.

[55] Ovie S. and Emma B : Identification and reduction of climate change vulnerability in the fisheries of Lake Chad Basin. FAO fisheries and Aquaculture proceedings 25: 23-71, 2012.

[56] Mekonnen D. T. The Lake Chad development and Climate resilience action plan (summary). Washington D. C.; world bank group. Retrieved 30 May 2016 from http://document.worldbank.org/curated/en/2016 L01/25811845/lake-chad-development-climateresilience-action-plan-summary, 2016.

[57] United Nations Environmental Programme (UNEP/ GRID)(2008): Drying up of Lake Chad (Atlas of our changing environment). Retrieved June $30^{\text {th }}$ fromhttp://www.na.unep.net. 2014.

[58] Luilo G. B.: Lake Victoria Water Resources Management Challenges and Prospects: a need for Equitable and Sustainable Institutional and regulatory frameworks. African Journal of Aquatic Science 33(2) 105-113 2008.

[59] Tungaraza C., Eliapende E., Osewe K. O. and Palapala P. M. Long-Term Climate Impact on the Lake Victoria Region Influences Water Level Fluctuation and Resource Availability. International Journal of Environmental Science. 2(3): 1717-1732. 2012. 